\title{
Design Models for Anaerobic Batch Digesters Producing Biogas from Municipal Solid Waste
}

\author{
Asinyetogha Hilkiah Igoni", Ibiye Sepiribo Kingnana Harry \\ Department of Agricultural \& Environmental Engineering, Faculty of Engineering \\ Rivers State University of Science and Technology, Nigeria \\ *Corresponding Author: ahigoni@yahoo.com
}

Copyright $\bigcirc 2017$ by authors, all rights reserved. Authors agree that this article remains permanently open access under the terms of the Creative Commons Attribution License 4.0 International License

\begin{abstract}
Models for the design of anaerobic batch digesters producing biogas from municipal solid waste (MSW) in Port Harcourt metropolis, Nigeria have been formulated. Experimental and field data were used to determine relevant design parameters for the batch digesters, especially the bio-kinetic behavior of MSW. The research data were analyzed using material balance analysis. The anaerobic digester was then designed and simulated for fractional conversion values of $0.2 \leq \alpha \leq 0.8$ and percentage total solids (PTS) concentration of $10-30 \%$, using Microsoft Visual Basic Version 6.0 computer program. The simulation results were interpreted with Microsoft Chart Editor. The evaluation of research results showed that an empirical optimum PTS concentration of $20 \%$ was best suited for the batch digester processing the MSW for biogas generation. At this level of PTS concentration, the MSW digestion was most effective in terms of digester sizing, time of digestion, volume of biogas produced and overall cost of the digester, for the same level of percent stabilization.
\end{abstract}

Keywords Anaerobic Batch Digester, Biogas Production, Municipal Solid Waste, Batch Digester design, Optimal Digester Performance

\section{Introduction}

The menace of municipal solid waste (MSW) in Port Harcourt metropolis, Nigeria has led to the development of several proposals on the best possible option to manage it. One veritable option is the introduction of a treatment component, which has been lacking, using anaerobic digestion. This reduces the waste volume and its pollution potential before final disposal. In anaerobic digestion, a useful by-product is biogas. Igoni et al [1] showed that MSW in Port Harcourt has the potential to be used as a source of biogas. For Nigeria, with large quantities of MSW generated, huge energy demand and a current inability to satisfy the energy needs of the citizenry, this option is attractive.

\subsection{Municipal Solid Waste}

Generally, waste is a useless and unwanted material. In contemporary times when alternative uses have been discovered for materials regarded as waste, there are now various and varied definitions of waste. Byrne [2] says waste is material, which has no direct value to the producer and so must be disposed of. Similarly, Bailie et al [3] explain that "for practical purposes, the term waste includes any material that enters the waste management system". A waste management system being organized programs and central facilities established not only for final disposal of waste but also for recycling, reuse, composting and incineration. They say "materials enter a waste management system when no one who has the opportunity to retain them wishes to do so". Therefore, a material that is considered waste and disposed by someone could be valuable to someone else.

Waste is classified according to the state of matter in which it occurs. Sincero and Sincero [4] say a gas that is wasted is a gas waste, such as polluted air from a process that is vented into the atmosphere; a liquid that is wasted, such as the polluted water of wastewater, is called a liquid waste; and a solid that is wasted is a solid waste. Hence, Ogunbiyi [5] states that solid waste is a non-fluid type of waste, which makes its handling and management relatively difficult, compared to the types of waste that can flow from one location to another, or even vaporize. According to Bailie et al [3], solid waste refers to all waste materials except hazardous waste, liquid waste and atmospheric emissions; and Kiely [6] says solid wastes are those wastes from human and animal activities including liquid wastes like paints, old medicines, spent oils etc. Therefore, it is possible to have solid waste intermixed with liquid waste. So, solid waste is essentially non-flowing. Igoni [7] enumerated various difficulties posed by solid waste arising from its non-flowing character. He listed such problems as offensive odours, obstruction of traffic flow, blocking of waterways/drain channels, leading to flooding of an area, destruction of environmental aesthetics and pollution of the air we breathe, with the concomitant unfavorable effects on public health.

An effective way to describe the relative toxicity of solid 
waste and provide solution to its menace, is to note its place of generation or point of origin. Accordingly, all waste collected by private and public authorities from domestic, commercial and some industrial (non-hazardous) sources is referred to as municipal solid waste [6]; and Bailie et al [3] say MSW comprises small and moderately sized solid waste items from houses, businesses, and institutions. For Byrne [2] MSW is generated from urban areas, particularly houses and shops.

In Port Harcourt, MSW management consists only of collection, transportation and disposal, which are improperly executed [8]. Therefore, introducing the anaerobic treatment component will be very useful in curbing the MSW menace and alleviating the energy crises in the area.

\subsection{The Concept of Biogas}

Biogas occurs when organic materials decompose in an oxygen-free environment. It has been described from different perspectives. Itodo and Philips [9] describe biogas as "a methane-rich gas that is produced from the anaerobic digestion of organic materials in a biological-engineering structure called the digester". GEMET [10] says biogas is "Gas rich in methane, which is produced by the fermentation of animal dung, human sewage or crop residues in an air-tight container". These definitions seem restricted to artificially produced biogas from named organic materials. What is decipherable is that it is only through controlled production that usable biogas is generated. Fig. 1 is a chart of the process and products of decomposition of organic waste.

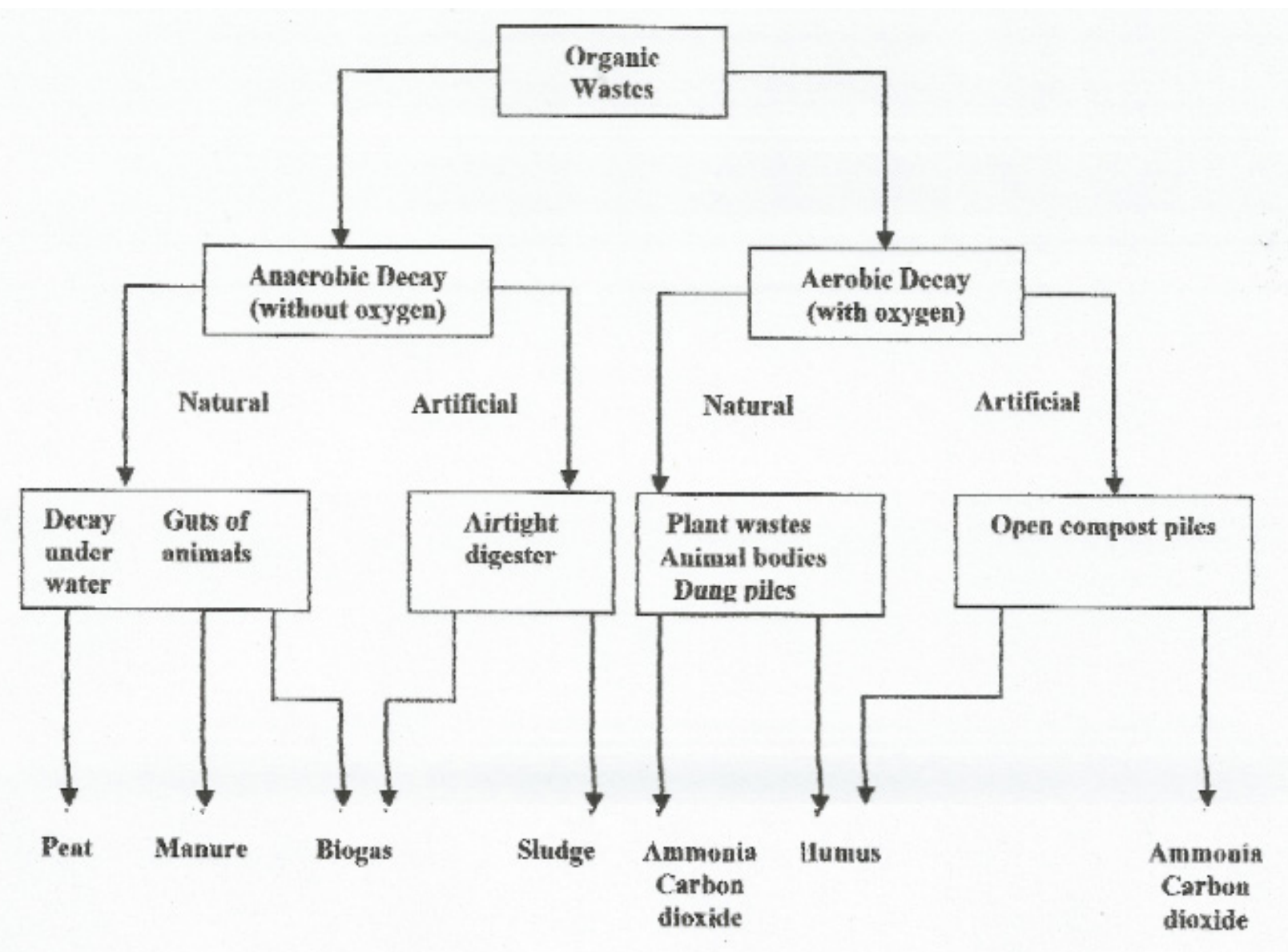

Figure 1. End products of organic decay 
The decomposition of organic matter in the absence of air could be by either physical or chemical processes at high temperature and/or pressure, or biological processes using microorganisms at low temperature and atmospheric pressure; the preferred method depending on their respective polluting impacts on the environment. Despite the method used, gas is produced, but is referred to as biogas if resulted from the action of microorganisms on the organic material [11]. Hence biogas could be defined as "a by-product of the biological breakdown, under oxygen-free conditions of organic wastes such as plants, crop residues, wood and bark residues, and human and animal manure, --- and is known by such other names as swamp gas, marsh gas, 'will o' the wisp' and gobar gas" [12]; landfill gas (LFG) \& sewage gas [13]; digestion gas [14]; Deep Green Energy [15]; and natural gas [16].

Biogas is a colorless, relatively odorless and inflammable gas, with the following composition [17] shown in Table 1, that burns with a blue flame and has a heat value of $4500-$ $5000 \mathrm{kcal} / \mathrm{m}^{2}$ when its methane content is in the range of $60-$ $70 \%$. It is also stable and non-toxic.

Table 1. Composition of biogas

\begin{tabular}{|c|c|}
\hline Constituents & \% Composition \\
\hline Methane $\left(\mathrm{CH}_{4}\right)$ & $55-75 \%$ \\
Carbon dioxide $\left(\mathrm{CO}_{2}\right)$ & $30-45 \%$ \\
Hydrogen Sulphide $\left(\mathrm{H}_{2} \mathrm{~S}\right)$ & $1-2 \%$ \\
Nitrogen $\left(\mathrm{N}_{2}\right)$ & $0-1 \%$ \\
Hydrogen $\left(\mathrm{H}_{2}\right)$ & $0-1 \%$ \\
Carbon Monoxide $(\mathrm{CO})$ & Traces \\
Oxygen $\left(\mathrm{O}_{2}\right)$ & Traces \\
\hline
\end{tabular}

\subsection{Research Objective}

The anaerobic processing of MSW in Port Harcourt requires the design of a reactor/digester, considering the properties of the MSW. Igoni et al [19] and Igoni et al [20] have presented the various properties of MSW in Port Harcourt and their applicability to the design of bioreactors for anaerobic digestion of the waste. There are different types of bioreactors that could be deplored in the anaerobic processing of MSW, including batch, plug-flow and continuously stirred tank reactors. The objective of this paper is to ease the design of anaerobic batch digesters for the processing of MSW in Port Harcourt metropolis, Nigeria by providing design models formulated for that purpose.

\section{Theory of Anaerobic Digester Design}

Digester design is based on the concept that organic materials degrade when acted upon by microorganisms. So the digester provides for the interaction of the waste and microbes under controlled environment. The degradation occurs either in the presence or absence of air, referred to as aerobic or anaerobic digestion respectively. When the organic component of MSW decomposes in the absence of air, biogas is given off. The decomposition process depends on the kinetic behaviour of the MSW, which in turn influences the design of any system for effective and efficient decomposition of the waste.

\subsection{Processes of Biogas Production}

Biogas results from "a biochemical process in which particular kinds of bacteria digest biomass in an oxygen-free environment" [15]. There are different types of bacteria that work together to break down complex organic wastes in stages, resulting in the production of biogas. This is why Chawla [21] says anaerobic digestion is "a bioreactor in which organic matter is progressively degraded in the absence of oxygen by a process known as methanogenesis". In earlier applications, anaerobic digestion was widely used for the treatment and stabilization of industrial, agricultural and municipal waters and sludge [12]. However, Kiely [6] notes that recently anaerobic digestion is also being applied to the treatment of MSW, with biogas generated only as a "waste product"

\subsection{Microbiological Processes in AD}

The $\mathrm{AD}$ process requires the organic waste and bacteria in an airtight environment. The bacteria use the organic waste as food and in the process break it down into various end products, which include biogas. The bacteria here are called facultative anaerobes, described as obligate anaerobes during methanogenesis.

The process is somewhat complex and occurs in several stages. Three basic stages: are i) liquefaction of solids; ii) digestion of soluble solids, and iii) gas production [22], with four isolated trophic microbiological groups: i) hydrolysis; ii) acidogenesis; iii) acetogenesis; and iv) methanogenesis [6], have been identified. However, Stewart [23] enlist several authors who have described AD as a three phase-, four phase-, five phase- and nine phase processes respectively, which, according to him, are indicative of the complexity of the microbial systems involved in the process. Generally, the predominant four stages are described thus:

- Hydrolysis: - The breakdown of complex polymeric materials like proteins, carbohydrates, lipids, fats and grease by extracellular enzymes into simpler soluble products, small enough to pass through the cell membrane of the microorganism.

- Acidogenesis: - Where the lower molecular components of fatty acids, amino acids and monosaccharides are fermented to short-chain fatty acids, alcohols, ammonia, hydrogen and carbon dioxide.

- Acetogenesis: - This is often considered as a part of acidogenesis. The short-chain fatty acids are converted to acetate, hydrogen, and carbon dioxide

- Methanogenesis: - This is the final stage of methane production from hydrogen by hydrogenophillic 
methanogens and from acetate by aceticlastic methanogens.

Eckenfelder [24] described the breakdown of carbohydrates, nitrogenous compounds and fats using the chemical formula:

$$
\mathrm{C}_{6} \mathrm{H}_{12} \mathrm{O}_{6}+2 \mathrm{H}_{2} \mathrm{O} \rightarrow 2 \mathrm{C}_{2} \mathrm{H}_{4} \mathrm{O}_{2}+2 \mathrm{CO}_{2}+4 \mathrm{H}_{2}
$$

From the acetic acid and hydrogen products of the above reaction, methane would be produced thus:

$$
\begin{aligned}
& 2 \mathrm{C}_{2} \mathrm{H}_{4} \mathrm{O}_{2} \rightarrow 2 \mathrm{CH}_{4}+2 \mathrm{CO}_{2} \\
& 4 \mathrm{H}_{2}+2 \mathrm{CO}_{2} \rightarrow \mathrm{CH}_{4}+2 \mathrm{H}_{2} \mathrm{O}
\end{aligned}
$$

When these expressions are combined, the generalized equation for the anaerobic digestion process is obtained as follows:

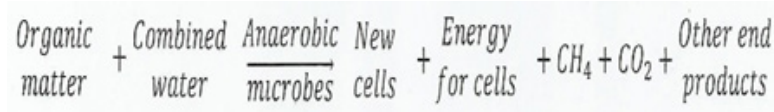

\subsection{Reaction Mechanism of Anaerobic Digestion}

The anaerobic digestion reaction is usually described as a first order process using the rate equation (5), where the rate of increase in biomass is proportional to the initial biomass concentration.

$$
r_{x}=\frac{d[X]}{d t}=\mu[X]
$$

$\mathrm{r}_{\mathrm{x}}$ - growth rate of biomass, $\mathrm{mg} / \mathrm{l} / \mathrm{day}$

$\mathrm{X}$ - concentration of biomass, $\mathrm{mg} / \mathrm{l}$

$\mu$ - specific growth rate of the mixed population

$\left(\right.$ days $\left.^{-1}\right)=$ mass of cells produced / mass of cells present per unit time

$\mathrm{t}$ - time, days

By first-order kinetics, if $\mathrm{X}_{\mathrm{o}}$ represents the biomass at time, $\mathrm{t}=0$, then integrating equation (5) gives:

$$
\begin{gathered}
\int_{x_{o}}^{x} \frac{d[X]}{[X]}=\mu \int_{o}^{t} d t \\
\operatorname{In}[X]=\operatorname{In}\left[X_{o}\right]+\mu t \\
\operatorname{In}\left(\frac{[X]}{\left[X_{o}\right]}\right)=\mu t \\
{[X]=\left[X_{o}\right] \exp ^{(\mu t)}}
\end{gathered}
$$

This expression describes the exponential growth rate of microbes, which is not a generalization, particularly for the batch culture where environmental conditions change during its lifetime. Considering a 'fraction of the reactant converted to the product' describe as fractional conversion, $(\alpha)$ [25], such that if $X_{o}$ is the initial concentration of the reactant, and $\mathrm{X}$ is the concentration of the reactants at any point in time, $\mathrm{t}$, then the conversion of the reactants in a constant-volume system will be:

$$
\alpha=\frac{X_{o}-X}{X_{o}}=1-\frac{X}{X_{o}}
$$

and

$$
d \alpha=\frac{d X}{X_{o}}
$$

If the rate equation is expressed in terms of the fractional conversion, then:

$$
\frac{d \alpha}{d t}=\mu(1-\alpha)
$$

which, upon rearrangement and integration becomes:

$$
\int_{0}^{\alpha} \frac{d \alpha}{1-\alpha}=\mu \int_{0}^{t} d t
$$

or

$$
-\ln (1-\alpha)=\mu t
$$

and a plot of $\ln (1-\alpha)$ or $\ln \left(\frac{X}{X_{o}}\right)$ against time is expected to produce a straight line through the origin.

\section{Materials and Methods}

\subsection{Bench-scale Reactor Experimentation}

Five batch-wise anaerobic digesters of 5 litres each were used for the experimental set up. A schematic of a single digester set-up is shown in Fig. 2.

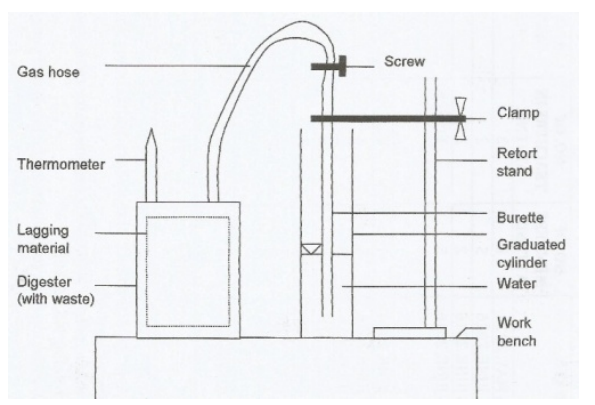

Figure 2. Schematic diagram of the batch reactor experimentation design layout

The digesters were improvised with large cans because of the limitation of the unavailability of model digesters, but deriving substantial impetus from Hobson et al. [11], who said "with a batch digester a smaller experimental system may be suitable as the digester has only to be loaded once and may not even need to be stirred. One or two litres could be big enough". The containers were properly lagged with wool material of about $25 \mathrm{~mm}$ thickness, to minimize the interaction between the temperatures inside and outside of the digesters.

Two perforations were made on the cover of the digester through which the gas hose and thermometer were fitted. The hose extending from the digester top was connected to the tail of a burette, which in turn was then partly immersed in water in a graduated cylinder. The waste materials were processed (shredded and mashed), and the digesters were then loaded with $2 \mathrm{~kg}$ of organic MSW, which was diluted 
to a $26.7 \%$ total solids (TS) concentration after metals, glass and other non-biodegradable materials had been removed.

The properties of MSW relevant to its anaerobic biodegradation was investigated and presented by Igoni et al. [20]. The TS concentration was determined by adopting the procedure for the determination of TS outlined in 2540 $\mathrm{G}$ of Standard Methods for the Examination of Water and Waste Water [26]; and the moisture content was determined by the oven-drying method.

The $\mathrm{pH}$ was measured from a digital $\mathrm{pH}$ meter, and the substrate and biomass concentrations, were respectively determined in terms of the chemical oxygen demand (COD), and the mixed liquor volatile suspended solids (MLVSS) using the respective procedures in 5220 b.4b and $2540 \mathrm{G}$ of Standard Methods for the Examination of Water and Waste Water. The carbon and nitrogen contents were determined, from where the carbon to nitrogen $(\mathrm{C}: \mathrm{N})$ ratio was computed. The carbon was determined by adapting the Walkley-Black method for determining soil organic matter [27], and the nitrogen was determined with the usual macro-Kjedahl method. The thermometer, was passed into the headspace of the digester, and measured the temperature of the headspace inside of the digester. The ambient temperature was measured from maximum and minimum thermometers at the same time. These temperature measurements were taken at 0800 hours and 1400 hours, and aimed at determining temperature variation within and outside the digester, to ensure proper digester insulation with respect to digester construction materials. After these initial measurements from the waste replications, the digesters were made airtight with glue and other adhesives, and the set-up allowed running. Each of the digesters was dismantled at intervals of 5 days, which gave the experimentation a total lifespan of 25 days. At each dismantling, substrate (COD) and microbial (MLVSS) concentration measurements were repeated. The full view of the reactor experimentation set-up is shown in Fig. 3.

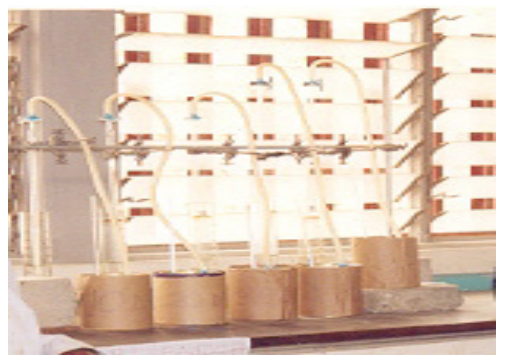

Figure 3. Full view of digesters experimental set-up

\subsection{Design Models Formulation}

A variety of models have been developed for the design of digesters, and evaluation of digester operation and performance. However, these models are generalized, and their use for the description of any digester depends on the type, characteristics, and location of the waste [11]. Hence the necessity to formulate appropriate models for the design and assessment of the digesters using MSW generated in Port Harcourt metropolis.

\subsubsection{Material balance of the anaerobic digestion process}

The basic design approach for an anaerobic bioreactor is the formulation of models for the reactor process, based on an analysis of material balances during the processes. Several literatures ([28]; [6]; [22]; and [29]) state the general form of a material balance expression as follows:

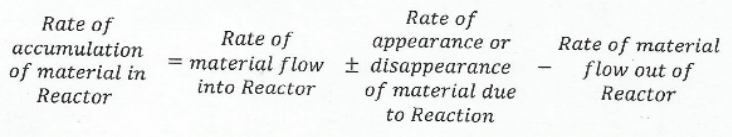

This is further simplified as:

Accumulation $=$ Inflow + Net growth - Outflow

and considering the anaerobic digestion process, this expression can be symbolically represented as:

$$
\frac{d[X]}{d t} V_{r}=Q\left[X_{o}\right]+V_{r} \mu_{n e t}-Q[X]
$$

i.e: $\frac{d[X]}{d t}$ - rate of change of microorganism concentration in the reactor measured in terms of mass (mixed liquor volatile suspended solids), mass MLVSS/unit volume. time

$\mathrm{V}_{\mathrm{r}}$ - volume of reactor

$\mathrm{Q}$ - flowrate, volume / time

$\mathrm{X}_{\mathrm{O}}$ - concentration of microorganisms in influent, mass MLVSS/unit volume

$\mathrm{X}$ - concentration of microorganism in reactor, mass MLVSS/unit volume

$\mu_{\text {net }}$ - net rate of micro-organisms growth, mass MLVSS/unit volume time

By Monod [30] kinetics

$$
\mu=\mu_{\max } \frac{[S]}{K_{s}+[S]}
$$

$\mu$ max - maximum growth rate, days-1

$\mathrm{S}$ - concentration of limiting substrate, $\mathrm{mg} / \mathrm{l}$

$\mathrm{Ks}$ - half saturation constant (i.e. concentration of $\mathrm{S}$ when $\left.\mu=\frac{\mu_{\max }}{2}\right), \mathrm{mg} / \mathrm{l}$ and

$$
\mu_{n e t}=\mu_{\max } \frac{[S]}{K_{s}+[S]}[X]-k_{d}[X]
$$

then,

$$
\frac{d[X]}{d t} V_{r}=Q\left[X_{o}\right]+V_{r}\left(\mu_{\max } \frac{[S]}{K_{s}+[S]}[X]-k_{d}[X]\right)-Q[X]
$$

$$
\frac{d[X]}{d t} V_{r}=Q\left(\left[X_{o}\right]-[X]\right)+V_{r}\left(\mu_{\max } \frac{[S]}{K_{s}+[S]}[X]-k_{d}[X]\right)
$$

This represents the general model for the anaerobic digestion process 


\section{Results and Discussion}

The experimental results for the batch anaerobic digestion of the MSW are presented in Tables $2 \& 3$.

\subsection{Application of the Material Balance to Batch Reactor Processes}

Applying the general form of the material balance expression to a batch process where there is no flow (i.e. $\mathrm{Q}=0$ ), the first term of the right hand side of the equation becomes zero;

$$
\text { i.e. } Q\left(\left[X_{o}\right]-[X]\right)=0
$$

(a) Material Balance for Mass of Microorganism

$$
\begin{aligned}
& \therefore \quad \frac{d[X]}{d t} V_{b d}=\frac{\mu_{m}[S][X]}{K_{s}+[S]} V_{b d}-k_{d}[X] V_{b d} \\
& \left.\quad \text { or (eliminating } \mathrm{V}_{\mathrm{bd}}\right) \frac{d[X]}{d t}=\frac{\mu_{m}[S][X]}{K_{s}+[S]}-k_{d}[X]
\end{aligned}
$$

and this represents the mass balance for the mass of microorganisms in the batch reactor.

\section{(b) Material Balance for Total Substrate Utilization}

The material balance for the total substrate utilization in a batch process is equally given as;

$$
\frac{d[S]}{d t} V_{b d}=-\frac{k[S][X]}{K_{s}+[S]} V_{b d}
$$

or (eliminating $\mathrm{V}_{\mathrm{bd}}$ )

$$
\frac{d[S]}{d t}=-\frac{k[S][X]}{K_{S}+[S]}
$$

$\mathrm{k}$ - maximum rate of substrate utilization per unit mass of cells produced (mass/mass, time) and

$$
k=\frac{\mu_{m}}{Y}
$$

The solution of equation (21b) is as follows:

$$
\begin{gathered}
\frac{d t}{d[S]}=-\frac{K_{s}+[S]}{k[S][X]} \\
\frac{d t}{d[S]}=-\frac{K_{s}}{k[S][X]}-\frac{1}{k[X]} \\
d t=-\frac{K_{s} d S}{k[S][X]}-\frac{d S}{k[X]} \\
\int_{t=0}^{t=t} d t=\int_{S_{o}}^{S_{e}} \frac{K[S][X]}{k[S}-\int_{S_{o}}^{S_{e}} \frac{d S}{k[X]}
\end{gathered}
$$

so that

$$
t=\frac{K_{s}}{k[X]} \ln \left(\frac{S_{o}}{S_{e}}\right)+\frac{\left[S_{o}\right]-\left[S_{e}\right]}{k[X]}
$$

This is the time for batch digestion required to achieve a given fractional conversion $(\alpha)$, obtained from a computer solution of the equation using Simpson's numerical approximation, thus:

Let ' $\mathrm{N}$ ' represent the range of integration, such that $\mathrm{N}=10$ Then interval

$$
h=\frac{\left(S_{e}-S_{o}\right)}{N}
$$

such that

$$
\begin{gathered}
\mathrm{S}(\mathrm{N})=\mathrm{S}_{\mathrm{o}}+(\mathrm{N} \times \mathrm{h}) \\
K_{s}+S(N) \\
\left.\begin{array}{c}
k[X] S(N)-k_{d}\left[K_{s}-S(N)\right] \\
\mathrm{S}(0)=\mathrm{f}(0)+\mathrm{f}(10) \\
\mathrm{S}(1)=\mathrm{f}(1)+\mathrm{f}(3)+\mathrm{f}(5)+\mathrm{f}(7)+\mathrm{f}(9) \\
\mathrm{S}(2)=\mathrm{f}(2)+\mathrm{f}(4)+\mathrm{f}(6)+\mathrm{f}(8)
\end{array}\right\}
\end{gathered}
$$

so that:

$$
t=\frac{h}{3}[S(0)+4 S(1)+2 S(2)]
$$

\subsection{Design Models for the Batch Digester}

The design of the anaerobic batch digester for MSW is the application of the properties of the MSW in the determination of digester parameters. Kiely [6] outlines the following parameters.

- $\quad$ Solids Retention Time (SRT), days

- Hydraulic Retention Time (HRT), days

- Volatile Solids Loading Rate, $\mathrm{kg} \mathrm{VS} / \mathrm{m}^{3} /$ day

- Solids Production Rate, $\mathrm{kg} \mathrm{SS} / \mathrm{m}^{3} /$ day

- Gas Production, $\mathrm{m}^{3}$ of $\mathrm{CH}_{4}$ of reactor/day

- Tank Configuration

- Mixing Systems

- Heating Systems

Accordingly, the following models have been formulated.

\subsubsection{Solids Retention Time (SRT)}

The SRT, the average period of time required for the material to remain in the system, is usually regarded as the most critical parameter in the system design, as it affects the treatment process performance, digester volume, sludge production etc. [29]. The SRT is also referred to as the mean cell residence time [22]; and the hydraulic retention time for first generation reactors [6]. It is defined as 


$$
\theta_{c}=\frac{X}{\Delta X}
$$

$\theta_{\mathrm{c}}$ - mean cell residence time, days

$\mathrm{X}$ - amount of dry solids in the digester, $\mathrm{kg}$

$\Delta \mathrm{X}$ - amount of dry solids produced per day in the digested sludge, $\mathrm{kg}$

There is a minimum mean cell residence time, $\theta_{c}^{m}$, below which the cells are washed from the system faster than they can multiply, and therefore waste stabilization does not occur. This critical value of $\theta_{c}$ is defined mathematically as:

$$
\frac{1}{\theta_{C}^{m}}=\frac{Y K S}{K_{S}+S}-k_{d}
$$

$\theta_{c}^{m}$ - minimum mean cell residence time

In many practical situations, $\mathrm{S}$ is much greater than $\mathrm{K}_{\mathrm{s}}$ that the equation (25a) can be rewritten as:

$$
\frac{1}{\theta_{C}^{m}}=Y K-k_{d}
$$

and the ratio of $\theta \mathrm{c}$ to $\theta_{\mathrm{c}}^{\mathrm{m}}$ is described as the process safety factor (SF)

$$
S F=\frac{\theta_{C}}{\theta_{C}^{m}}
$$

\subsubsection{Volatile Solids Loading Rate (VSLR)}

The VSLR is very relevant in digester sizing. It is defined as:

$$
\begin{gathered}
\text { VS loading rate }= \\
=\frac{\text { Volatile solids added daily, } \mathrm{kg} \mathrm{VS} / \text { day }}{\text { Working volume of the digester, } \mathrm{m}^{3}}
\end{gathered}
$$

The upper limit of volatile solids loading rates is typically determined by the rate of accumulation of toxic materials, particularly ammonia or washout of methane formers. This leads to very low methane production. On the other hand, excessively low volatile solids loading rates can result in designs that are costly to build and are troublesome to operate. Closely related to the VSLR is the volatile solids destruction (VSD), which indicates the amount of volatile solids reduced during the digestion process. Tchobanoglous et al [29] explain that "the degree of stabilization obtained is often measured by the percent reduction in volatile solids.

\subsubsection{Digester Volume}

This depends on volume of fresh sludge added daily; the volume of digested sludge produced daily; and the required digestion time in days; and that additional volume provision must be made for the supernatant liquor, gas storage, and storage of digested sludge [22]. They state that the volume of the remaining digesting sludge versus the digestion time (i.e. average volume of digesting sludge) is a parabolic function thus:

$$
V_{\text {avg }}=V_{1}-\frac{2}{3}\left(V_{1}-V_{2}\right)
$$

$\mathrm{V}_{\text {avg }}$ - average volume of digesting sludge $\mathrm{m}^{3} /$ day

$\mathrm{V}_{1}$ - volume of fresh sludge added daily $\mathrm{m}^{3} /$ day

$\mathrm{V}_{2}$ - volume of digested sludge produced daily, $\mathrm{m}^{3} /$ days, which is the same as the final sludge volume

$\mathrm{t}$ - retention time

Again the volume of total sludge in the digester (both digesting and digested sludge) is given by

$$
\mathrm{V}_{\mathrm{s}}=\mathrm{V}_{\mathrm{avg}} \cdot \mathrm{t}_{\mathrm{d}}+\mathrm{V}_{2} \cdot \mathrm{t}_{\mathrm{s}}
$$

$\mathrm{V}_{\mathrm{s}}$ - total sludge volume, $\mathrm{m}^{3}$

$t_{d}$ - time required for digestion, days

$t_{s}$ - time provided for sludge storage, days

Taking sludge volume to account for two-thirds $(2 / 3)$ of the total volume [6], then the total volume of the batch digester will be:

$$
\mathrm{V}_{\mathrm{bd}}=3 / 2 \mathrm{~V}_{\mathrm{s}}
$$

$\mathrm{V}_{\mathrm{bd}}$ - total batch digester volume, $\mathrm{m}^{3}$

Substituting equations (28 and 29) into equation (30) gives:

$$
\begin{gathered}
\mathrm{V}_{\mathrm{bd}}=3 / 2\left(\mathrm{~V}_{\mathrm{avg}} \cdot \mathrm{t}_{\mathrm{d}}+\mathrm{V}_{2} \cdot \mathrm{t}_{\mathrm{s}}\right) \\
V_{b d}=\frac{3}{2}\left\{\left[V_{1}-\frac{2}{3}\left(V_{1}-V_{2}\right)\right] t_{d}+V_{2} t_{s}\right\} \\
V_{b d}=\frac{3}{2}\left[\left(V_{1}+2 V_{2}\right) \frac{t_{d}}{3}+V_{2} t_{s}\right] \\
V_{b d}=\frac{1}{2}\left[\left(V_{1}+2 V_{2}\right) t_{d}+3 V_{2} t_{s}\right]
\end{gathered}
$$

\subsubsection{Digester Tank Configuration}

This is a description of the shape of the digester; the relationship between the digester size parameters. Tchobanoglous and Burton [31] say "anaerobic digestion tanks are either cylindrical, rectangular or egg-shaped". Whereas these different digester configurations have inherent advantages due mainly to their efficiency of mixing of the contents, cleaning of the inside of the digester walls, and unloading the digester, eliciting their use in different circumstances, Kiely [6] states that anaerobic digester "tank configurations are now primarily cylindrical with diameters of 5 to $50 \mathrm{~m}$ and heights of 3 to $25 \mathrm{~m}$ ". These size-ranges clearly put the digester diameter-to-height ratio at 2:1.

This design adopts the cylindrical configuration because of the type of waste, which has large particle sizes. Therefore, with a known volume of digester tank the diameter and height of the digester could be determined as follows:

$$
V_{b d}=A_{b d} x H_{b d}
$$

$\mathrm{A}_{\mathrm{bd}}$ - cross-sectional area of batch digester, $\mathrm{m}^{2}$

$\mathrm{H}_{\mathrm{bd}}$ - height of batch digester, $\mathrm{m}$

But A, the cross-section area of a cylinder is given as: 


$$
A_{b d}=\frac{\pi D_{b d}^{2}}{4}
$$

$\mathrm{D}_{\mathrm{bd}}$ - diameter of the batch digester

So, since $H_{b d}=\frac{D_{b d}}{2}$ it follows that the digester

volume will now be.

$$
V_{b d}=\frac{\pi D_{b d}^{2}}{4} \cdot \frac{D_{b d}}{2}
$$

Or

$$
V_{b d}=\frac{\pi D_{b d}^{3}}{8}
$$

from where

$$
D_{b d}=\sqrt[3]{\frac{8 V_{b d}}{\pi}}
$$

and therefore

$$
H_{b d}=\sqrt[3]{\frac{8 V_{b d}}{\pi}} /
$$

\subsubsection{Model for Digester Mixing}

Anaerobic batch digester mixing is usually achieved with an auger/screw conveyor because of the relatively high solids content of the mixture. Raymus [32] says "Almost any degree of mixing can be achieved with screw-conveyor flights cut,..." and that the power required for the screw-conveyor is composed of the power necessary to drive the screw empty and to move the material. The first component depends on conveyor length, speed of rotation, and friction in the conveyor bearings, while the second depends on the total weight of material conveyed per unit time, conveyed length, and depth to which the trough is loaded. The latter power item is in turn a function of the internal friction and friction on metal of the conveyed material. A wide range of capacities and power requirements for various sizes of screws handling up to $801 \mathrm{~kg} / \mathrm{m}^{3}$ of material of average conveyability has been prescribed. Evseev et al [33] present the productivity of an auger transporter as in equation (37):

$$
Q_{A U G}=60 \cdot \frac{\pi\left(D^{2}-d^{2}\right)}{4} \cdot S \cdot n \cdot \wp \cdot \varphi
$$

$\mathrm{Q}_{\mathrm{AUG}}$ - capacity of the auger, tons/hr

$\mathrm{D}$ - outer diameter of auger, $\mathrm{m}$

$\mathrm{d}$ - inner diameter of auger (i.e. diameter $\mathrm{r}$ of shaft), $\mathrm{m}$

$\mathrm{S}$ - pitch of auger, $\mathrm{m}$

$\mathrm{n}$ - speed of auger, rpm $\wp$ - specific weight of material to be moved, tons $/ \mathrm{m}^{3}$

$\varphi$ - coefficient of fill of material $\approx 0.25$ to 0.40

Normally, $\mathrm{S}=(0.75$ to 1.0$) \mathrm{D}$ and $\mathrm{d}=(0.25$ to 0.35$) \mathrm{D}$

\subsubsection{Digester Heating}

The digester is designed to operate at ambient temperature of $35^{\circ} \mathrm{C}$. To maintain this mesophillic condition, external heaters are used, where "the sludge is pumped at high velocity through the tubes, while water circulates at high velocity around the outside of the tubes" [29]. The circulation of water promotes high turbulence on both sides of the heat transfer surface and results in higher heat transfer coefficients and better heat transfer. Reynolds and Richards [22] say the use of an external heater, which heats the pumped sludge outside the digester, controls the problem of caking associated with internally heated digesters, since any sludge caking will occur in the pipes in the heat exchanger. It allows for de-caking of the pipes and enhances digester maintenance and high heat transfer efficiency.

\subsubsection{Heater Requirements}

\section{(i) Required Quantity of Water for Heating}

The specific digester heat requirement is defined as:

$$
q_{t}=M_{w} C_{w}\left(T_{d}-T_{o}\right)
$$

$M_{w}$ - mass flow rate of hot water, kg.s ${ }^{-1}$

$\mathrm{C}_{\mathrm{w}}$ - specific heat of hot water, $\mathrm{J}_{\mathrm{kg}}{ }^{-1} \cdot{ }^{\circ} \mathrm{C}$

$$
\therefore \quad M_{w}=\frac{q_{t}}{C_{w}\left(T_{d}-T_{o}\right)}
$$

\section{(ii) Required Surface Area for Heat Exchange}

The heat flow across the walls of a tube is described in equation (40)

$$
Q_{N}=U A \Delta T
$$

$\mathrm{Q}_{\mathrm{N}}$ - Net heat transfer into the digester. J.s ${ }^{-1}$

$\mathrm{U}$ - heat transfer coefficient, $\mathrm{J}_{\mathrm{m}} \mathrm{m}^{-2} . \mathrm{s} .{ }^{\circ} \mathrm{C}$

$\Delta \mathrm{T}$ - temperature difference between digester and incoming sludge, ${ }^{\circ} \mathrm{C}$

For the externally heated digester, ' $\mathrm{A}$ ' in the above equation is the surface area with which heat is exchanged with the incoming sludge stream to the digester; and $U=U_{w}$. Therefore,

$$
\begin{gathered}
A=\frac{Q_{N}}{U\left(T_{d}-T_{S}\right)} \\
A=2 \pi r l
\end{gathered}
$$

$\mathrm{r}$ - radius of heat exchanger pipe, $\mathrm{m}$

1 - length of pipe in water bath, $m$ 


\subsubsection{Model for Digester Cost Estimation}

Initial capital investment in the manufacture of anaerobic digesters is estimated as a function of an existing digester with similar characteristics. This is why it is somewhat difficult to achieve adequate estimation, as there are very few commercial digesters in operation. However, Peter and Timmerhaus [34] presented the power factor equation, which gives a fairly accurate estimate.

$$
X=Y\left(\frac{C_{2}}{C_{1}}\right)^{0.6}
$$

$\mathrm{X}$ - cost of proposed digester,

Y - current cost of existing digester,

$\mathrm{C}_{1}$ - capacity of existing digester with known cost

$\mathrm{C}_{2}$ - capacity of proposed digester

This empirical formulation considers the price index of the base year of manufacture of the digester with known cost. So the actual capital cost of the proposed digester would be obtained relative to the price index of the current year. The first step is to use the relative price indices of the respective years to determine what would have been the actual cost of the digester with known cost and capacity in the current year. Whitesides [35] said "cost indices must be used when basing the approximated cost on other than current prices". He states that the known cost of the digester must be multiplied by the ratio of the cost index of the current year to that of the base year. This translates mathematically thus:

$$
Y=C_{o}\left(\frac{I}{I_{o}}\right)
$$

$\mathrm{C}_{0}$ - base cost of existing digester,

I - current price index

$\mathrm{I}_{\mathrm{o}}$ - base price index

When this is related to the power factor equation, then, the estimated cost of the proposed digester will be:

$$
X=C_{o}\left(\frac{I}{I_{o}}\right)\left(\frac{C_{2}}{C_{1}}\right)^{0.6}
$$

\subsubsection{Models for Methane and Biogas Production}

The basic stoichiometric equation (46) presented by Buswell and Mueller [36] in Kiely [6] is used to determine the amount of methane $\left(\mathrm{CH}_{4}\right)$.

$$
\mathrm{C}_{n} \mathrm{H}_{a} \mathrm{O}_{b}+\left[n-\frac{a}{4}-\frac{b}{2}\right] \mathrm{H}_{2} \mathrm{O} \rightarrow\left[\frac{n}{2}-\frac{a}{8}+\frac{b}{4}\right] \mathrm{CO}_{2}+\left[\frac{n}{2}+\frac{a}{8}-\frac{b}{4}\right] \mathrm{CH}_{4}
$$

The volume of biogas produced is estimated by predicting the volume of methane gas and applying the equation (46).

Considering an organic matter represented as $\mathrm{C}_{6} \mathrm{H}_{10} \mathrm{O}_{5}$, such that $\mathrm{n}=6, \mathrm{a}=10$ and $\mathrm{b}=5$, then the following chemical relationship can be established.

$$
\mathrm{C}_{6} \mathrm{H}_{10} \mathrm{O}_{5}+\mathrm{H}_{2} \mathrm{O} \rightarrow 3 \mathrm{CO}_{2}+3 \mathrm{CH}_{4}
$$

Knowing that the molecular weights: $\mathrm{C}_{6} \mathrm{H}_{10} \mathrm{O}_{3}=162$, $\mathrm{CO}_{2}=44$, and $\mathrm{CH}_{4}=16$, then from equation (47)

1 mole of $\mathrm{C}_{6} \mathrm{H}_{10} \mathrm{O}_{5} \equiv 3$ moles $\mathrm{CH}_{4}$

$1 \mathrm{~kg} \mathrm{C}_{6} \mathrm{H}_{10} \mathrm{O}_{5} \equiv 1000 \mathrm{~g} \equiv 1000 \mathrm{~g} / 162 \mathrm{~g} / \mathrm{mole}=6.173$ moles

6.173 moles $\mathrm{C}_{6} \mathrm{H}_{10} \mathrm{O}_{5}$ will yield $(6.173 \times 3)=18.519$ moles $\mathrm{CH}_{4}$.

Relying on Avogadro's postulation, then 1 mole of $\mathrm{CH}_{4} \equiv 0.0224 \mathrm{~m}^{3}$.

Therefore, 18.519 moles $\mathrm{CH}_{4} \equiv 18.519 \times 0.0224=$ $0.415 \mathrm{~m}^{3}$. This shows that $1 \mathrm{~kg}$ of the organic matter would yield $0.415 \mathrm{~m}^{3}$ of $\mathrm{CH}_{4}$, which accounts for the difference in concentration of the MSW as it is digested from $\mathrm{S}_{\mathrm{o}}$ to $\mathrm{S}_{\mathrm{e}}$. Therefore, the unit of $\mathrm{CH}_{4}$ generated will be represented as:

$$
\mathrm{kg} / \mathrm{m}^{3} \text { of } \mathrm{CH}_{4} \text { produced }=0.415\left(\mathrm{~S}_{\mathrm{o}}-\mathrm{S}_{\mathrm{e}}\right)
$$

Then with a conversion factor $(\mathrm{M}=1.43)$ of COD to VS the equation becomes

$$
C_{m}=0.415 M\left(S_{o}-S_{e}\right)
$$

$\mathrm{C}_{\mathrm{m}}$-actual concentration of dissolved methane gas, $\mathrm{kg} \cdot \mathrm{m}^{-3}$

\subsubsection{Volume of Methane Produced}

The weight of gas transferred from a liquid to a gas region occurs across a liquid gas interface, with the interfacial area equal to the cross-sectional area of the digester. Therefore, the rate of diffusion in the gas-liquid contact system is described by the diffusion equation:

$$
\frac{d C_{g}}{d t}=-K_{L} \frac{A}{V_{L}}\left(C_{s t}-C_{m}\right)
$$

integrating

$$
C_{g}=K_{L} \frac{A}{V_{L}}\left(C_{s t}-C_{m}\right) t
$$

$\frac{d C}{d t}$ - rate of diffusion, $\mathrm{kg} \cdot \mathrm{m}^{-2} \cdot$ day

$\mathrm{K}_{\mathrm{L}}$ - diffusion coefficient, m.day ${ }^{-1}$

A - interfacial gas transfer area, $\mathrm{m}^{2}$

$\mathrm{V}_{\mathrm{L}}$ - volume of liquid, $\mathrm{m}^{3}$

$\mathrm{C}_{\mathrm{st}}$ - saturation concentration of gas in the liquid, $\mathrm{kg} \cdot \mathrm{m}^{-3}$

$\mathrm{C}_{\mathrm{g}}$ - concentration of methane gas in gas collector, $\mathrm{kg} \cdot \mathrm{m}^{-3}$

The saturation concentration of the gas is given as:

$$
C_{s t}=\frac{P_{m}}{H_{c}}
$$

$\mathrm{Pm}$ - partial pressure of the methane gas

Hc - Henry's constant

Graef and Andrews [37] said that for mesophilic digester, Henry's constant has been found as $3.25 \times 10-5 \mathrm{~mol} /$ $(1 / \mathrm{mmHg})$.

Mass of methane gas produced is:

$$
M_{m}=C_{g} x V_{g}
$$

And the volume is

$$
V_{m}=\frac{M_{m}}{\rho_{m}}
$$


$\mathrm{M}_{\mathrm{m}}$ - mass of methane gas, $\mathrm{kg}$

$\mathrm{V}_{\mathrm{g}}$ - volume of gas collector, $\mathrm{m}^{3}$

$\rho_{\mathrm{m}}$ - density of methane gas, $\mathrm{kg} / \mathrm{m}^{3}$

$\mathrm{V}_{\mathrm{m}}$ - volume of methane gas produced, $\mathrm{m}^{3}$

Perry and Green [38] give the density of methane as $0.644 \mathrm{~kg} / \mathrm{m}^{3}$

\subsubsection{Volume of Biogas Produced}

Considering biogas composition as $60 \%$ methane and $40 \%$ other constituents, then total volume of biogas produced would be:

$$
V_{t}=V_{m} \times \frac{100}{60}
$$

\subsubsection{Characteristics of Waste Effluent Concentration}

\subsubsection{Effluent Volatile Solids Concentration}

This is defined as:

$$
S_{e}=S_{e b}+R S_{o}
$$

$\mathrm{S}_{\mathrm{e}}$ - effluent VS concentration, $\mathrm{mg} / \mathrm{l}$

$\mathrm{S}_{\mathrm{eb}}$ - effluent biodegradable substrate concentration $\mathrm{mg} / \mathrm{l}$

$R-$ Refractory fraction $=\frac{\text { Concentration of refractory } V S}{\text { Concentration of influent } V S}$

\subsubsection{Effluent Biodegradable Substrate Concentration}

This is obtained as:

$$
S_{e b}=S_{i b}(1-\alpha)
$$

$\mathrm{S}_{\mathrm{ib}}$ - influent biodegradable substrate concentration, $\mathrm{mg} / \mathrm{l}$

$\alpha$ - fractional conversion

\subsubsection{Percentage Stabilization}

The efficiency of the waste stabilization system for biogas generation has been presented by Viessman and Hammer [39] as:

$$
E=\frac{\left(S_{o}-S_{e}\right) 100}{S_{o}}
$$

where: E - efficiency of removal of biodegradable waste load.

\subsection{Flowchart for the Digester Design}

The flowchart of the process design sequence is presented in Figure 4.

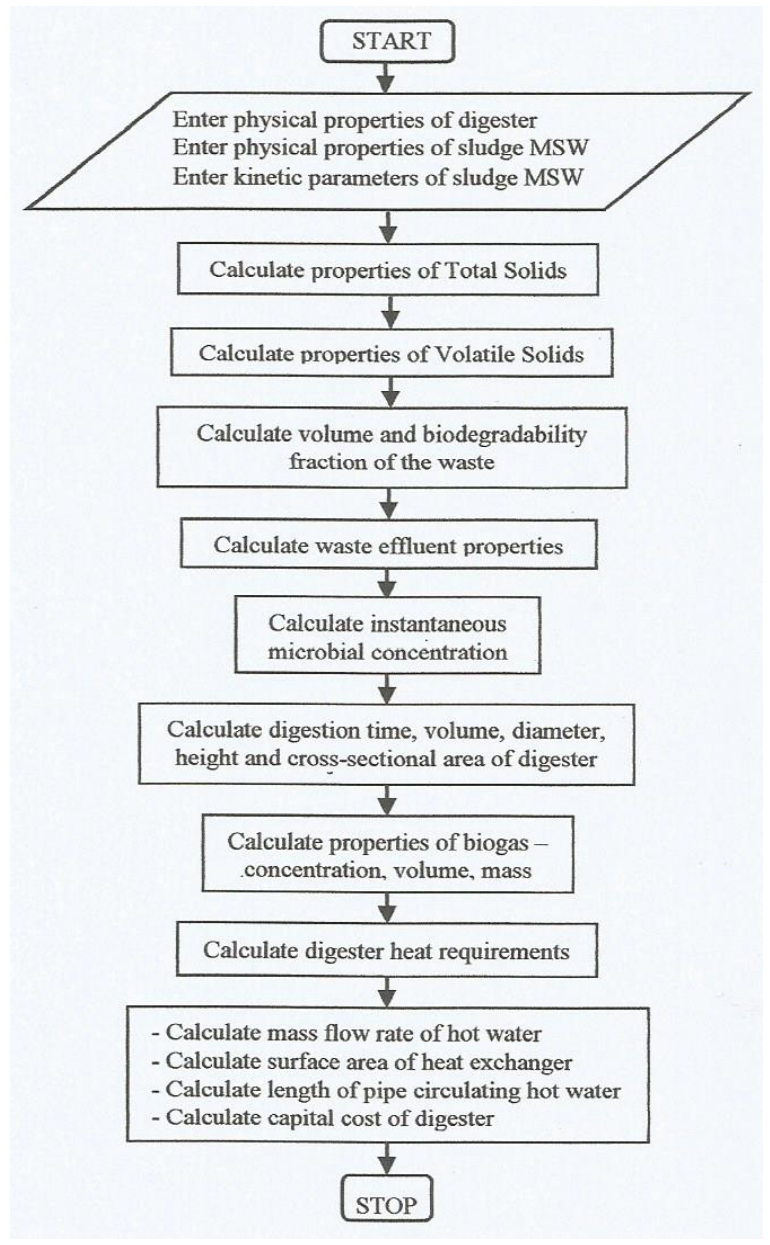

Figure 4. Flowchart for the digester design

\subsection{Validation of Design Models}

The digester design was simulated for fractional conversion values of $0.2-0.8$ and total solids concentration of $10-30 \%$. The values for the various digester parameters obtained from the design simulation were interrelated using Microsoft Chart Editor. Fig. 5 shows the relationship between the volume of digester and total solids concentration. The resulting curve is best fitted by a polynomial function of order 2, expressed in equation (58), with a correlation percentage of 92.2 .

$$
V_{d}=5 E-07(T S)^{2}-0.1133(T S)+17536
$$




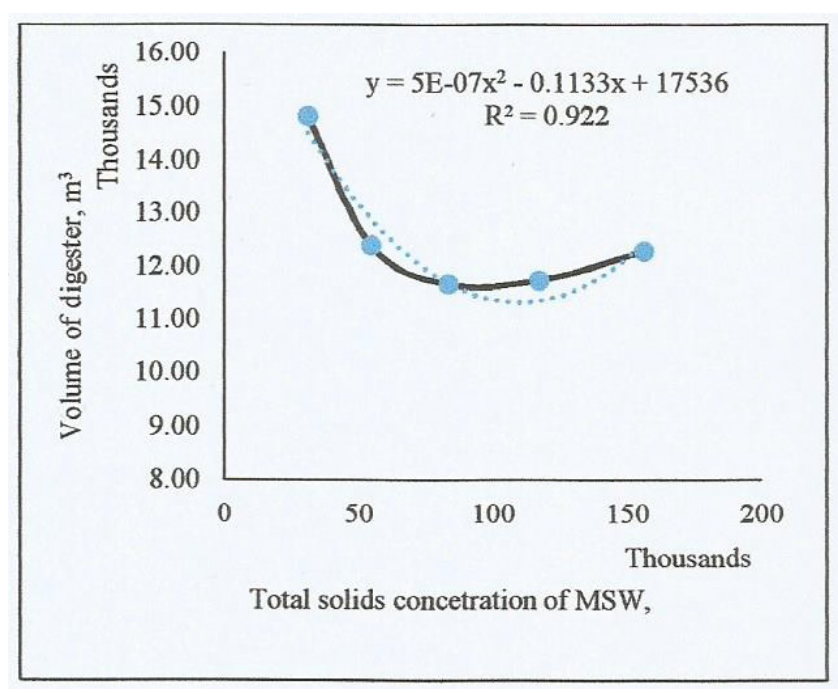

Figure 5. Effect of TS concentration of MSW on the volume of digester

The relationship shows declining values of volume of digester with increasing total solids concentration up to a level of percentage total solids concentration, when the volume began to rise. This indicates an optimum level of percentage total solids concentration of the MSW below and above which an increase in the volume of digester would not affect digester performance. This deduction is better understood from the curve of Fig. 6 and equation (59), which show the effect of TS on the time of digestion.

$$
t_{d}=-4 E_{-} 12(T S)^{2}+1 E_{-} 06(T S)+9.0259
$$

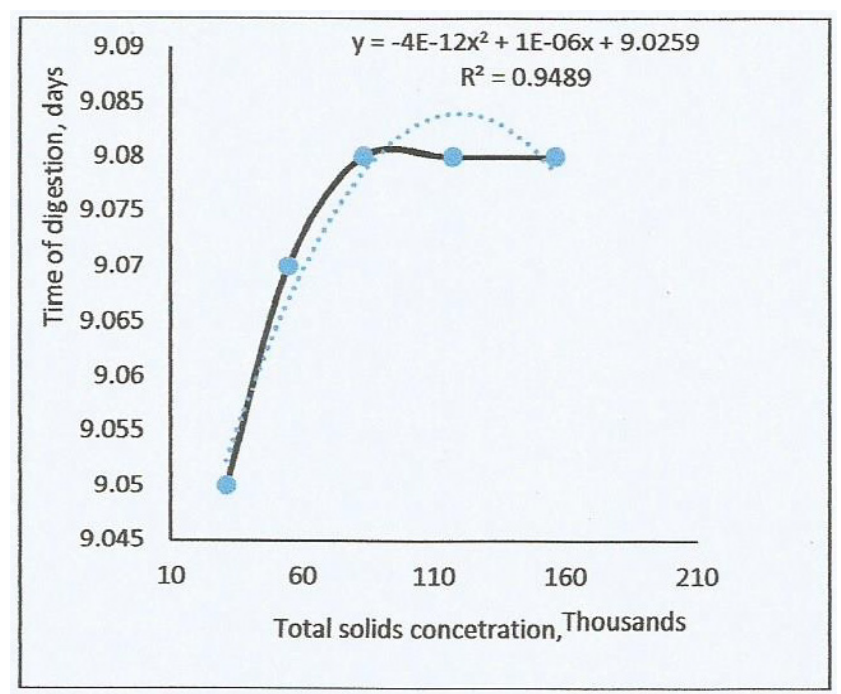

Figure 6. Effect of TS concentration of time of digestion

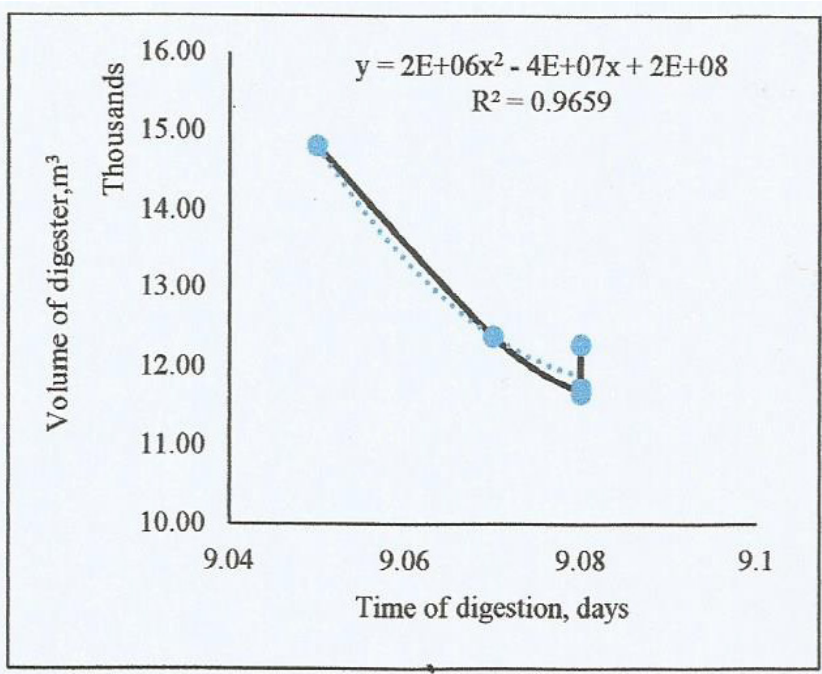

Figure 7. Variation of volume of digester with time of digestion

From the $20 \%$ TS concentration of $83,234.43$ (Table 9), any additional increment in PTS was digested in equal amounts of time, even up to $30 \% \mathrm{TS}$. The possibility here is that for a self-generating system without recycle, at any point below and above the $20 \% \mathrm{TS}$ the microbes were under generated. This is why Igoni et al [19] and Igoni [8] had stressed that the digestion of MSW for biogas generation would require an inoculum or a system with cell recycle for effective stabilization and biogas yield. The relationship established in Figs. 5 and 6 is clearly indicative of an empirical optimal value of $20 \%$ TS as the best suited for the anaerobic batch digestion of MSW in Port Harcourt metropolis. This finding is contrary to Tchobanoglous et al [40] that high solids digestion should be for total solids concentration of greater than or equal to $22 \%$. This feature is also shown in the relationship between volume and time of digestion in Fig. 7, represented by equation (60).

$$
V_{d}=2 E+06 t_{d}^{2}-4 E+07 t_{d}+2 E+08
$$

Figs. 8 and 9 are curves for the total amount of biogas generated and the net heat required by the digester, respectively, with respect to the volume of the digester. They are best suited by the exponential functions represented in equations (61) and (62).

$$
\begin{gathered}
V_{t}=5 E+06 e^{-5 E-04 x} \\
Q_{n}=1426.3 e^{-1 E-04 x}
\end{gathered}
$$




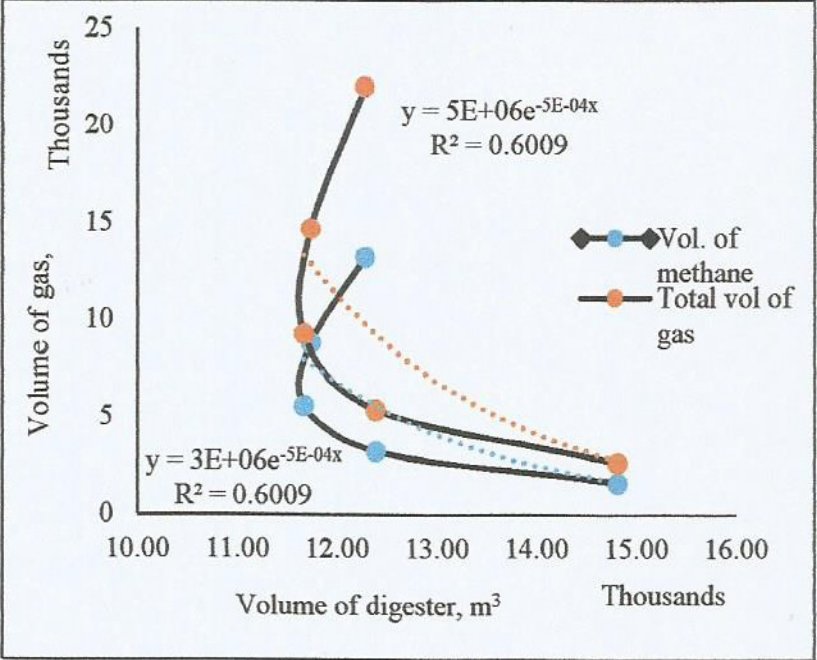

Figure 8. Variation of gas produced with volume of digester

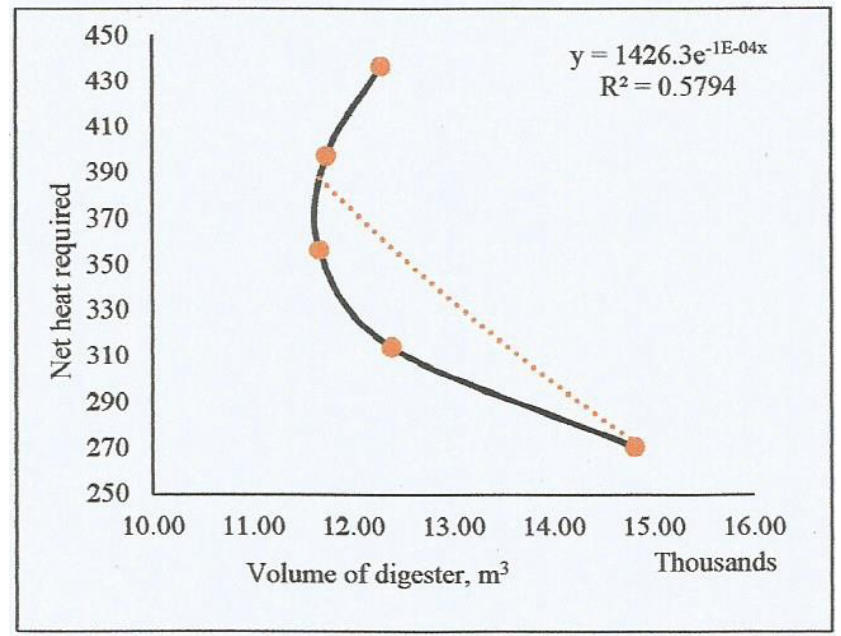

Figure 9. Relationship between net heat required and volume of digester

The curves show the same optimality relationship in the dependence of the $\mathrm{y}$-axis parameters on the volume of digester. On the hand Fig. 10, which is the dependence of cost on the volume of digester, is a power relationship, as the perfect fit. It shows that no matter the efficiency of the digester, the cost will continue to rise as the volume increases and in multiples. This is described by equation (63).

$$
X=2 E+06 V_{d}^{0.6}
$$

The cost is expressed in Naira (Nigeria's currency), but can be expressed in USD, using the prevailing exchange rate of $\$ 315.00$ to $\$ 1.00$.

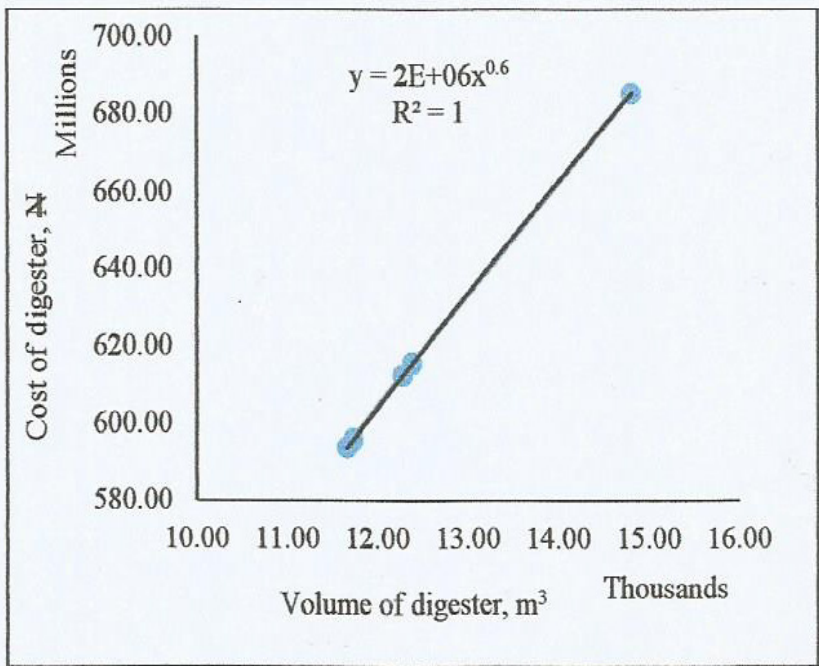

Figure 10. Variation of cost of digester with its volume

\section{Conclusions}

The management of MSW in Port Harcourt metropolis, Nigeria is lacking in several respects, especially that the waste is not treated in any form before final disposal. This, of course elicits dire consequences, especially because the untreated waste is dumped into borrow pits turned into makeshift dumpsites. The yearning for introduction of a treatment component for the processing of the waste can be addressed through anaerobic digestion of the waste in a batch system. The models formulated in this work would ease the design of anaerobic batch digesters in the production of biogas from municipal solid waste in the metropolis, as these have been developed considering the peculiar parameters of the waste. This development will inevitably address the twin problems of massive generation of MSW in the metropolis that has not been properly managed and, therefore, litters the whole locality; and the gross inadequacy of energy for local consumption. 


\section{Appendix}

\section{A. Experimental Results}

Table 2. Experimental batch digesters' data

\begin{tabular}{|c|c|c|c|c|c|}
\hline Digester no. & $\begin{array}{c}\text { Duration of } \\
\text { digestion, } t \text { (days) }\end{array}$ & $\begin{array}{c}\text { Initial MSW } \\
\text { concentration, } \mathrm{S}_{\mathrm{o}} \\
(\mathrm{mg} / \mathrm{l})\end{array}$ & $\begin{array}{c}\text { Effluent MSW } \\
\text { concentration, } \mathrm{S}_{\mathrm{e}}(\mathrm{mg} / \mathrm{l})\end{array}$ & $\begin{array}{c}\text { Initial microbial } \\
\text { concentration, } \mathrm{X}_{\mathrm{o}}(\mathrm{mg} / \mathrm{l})\end{array}$ & $\begin{array}{c}\text { Effluent microbial } \\
\text { concentration, } \mathrm{X}_{\mathrm{e}}(\mathrm{mg} / \mathrm{l})\end{array}$ \\
\hline- & 0 & 462.12 & - & 32.05 & - \\
\hline 1 & 5 & 462.12 & 328.77 & 32.05 & 114.31 \\
\hline 2 & 10 & 462.12 & 78.71 & 32.05 & 206.45 \\
\hline 3 & 15 & 462.12 & 26.49 & 32.05 & 137.45 \\
\hline 4 & 20 & 462.12 & 13.19 & 32.05 & 127.89 \\
\hline 5 & 25 & 462.12 & 5.43 & 32.05 & 12.87 \\
\hline
\end{tabular}

Table 3. Reduced data from batch experimentation for the determination of process kinetic parameters

\begin{tabular}{|c|c|c|c|c|c|c|c|}
\hline Digester no. & $\begin{array}{c}\text { Duration of } \\
\text { digestion, t (days) }\end{array}$ & $\bar{X}$ & $\bar{X} t$ & $\ln \left(\frac{S_{o}}{S_{e}}\right)$ & $\mathrm{S}_{\mathrm{o}}-\mathrm{S}_{\mathrm{e}}$ & $\frac{S_{o}-S_{e}}{\bar{X} t}$ & $\ln \left(\frac{S_{o}}{S_{e}}\right) / \bar{X} t$ \\
\hline- & 0 & - & 0 & 0 & - & - & - \\
\hline 1 & 5 & 73.18 & 365.9 & 0.340 & 133.35 & 0.364 & 0.000929 \\
\hline 2 & 10 & 119.25 & 1192.50 & 1.770 & 383.41 & 0.322 & 0.00148 \\
\hline 3 & 15 & 84.75 & 1271.25 & 2.859 & 435.63 & 0.343 & 0.00225 \\
\hline 4 & 20 & 79.97 & 1599.4 & 3.556 & 448.93 & 0.281 & 0.00222 \\
\hline 5 & 25 & 22.46 & 561.5 & 4.444 & 456.69 & 0.813 & 0.00791 \\
\hline
\end{tabular}

$\bar{X}=$ average cell mass concentration during the biochemical reaction - that is $\bar{X}=1 / 2\left(X_{0}+X_{t}\right)$,

where $X_{o}$ and $X_{t}$ are the cell mass concentrations at the respective times $t=0$ and $t=t[22]$

\section{B. Simulation results for the batch digester}

Table 4. Results at $10 \%$ TS

\begin{tabular}{|c|c|c|c|c|c|c|c|c|c|}
\hline$\alpha$ & $\begin{array}{c}\mathrm{Se} \\
(\mathrm{mg} / \mathrm{l})\end{array}$ & $\begin{array}{c}\mathrm{Xe} \\
(\mathrm{mg} / \mathrm{l})\end{array}$ & $\begin{array}{c}\mathrm{t}_{\mathrm{d}} \\
(\text { days })\end{array}$ & $\begin{array}{c}\mathrm{V}_{\mathrm{bd}} \\
\left(\mathrm{m}^{3}\right)\end{array}$ & $\begin{array}{c}\mathrm{E}_{\mathrm{b}} \\
(\%)\end{array}$ & $\begin{array}{c}\mathrm{V}_{\mathrm{m}} \\
\left(\mathrm{m}^{3} \mathrm{CH}_{4} / \mathrm{day}\right)\end{array}$ & $\begin{array}{c}\mathrm{V}_{\mathrm{t}} \\
\left(\mathrm{m}^{3}\right)\end{array}$ & $\begin{array}{c}\mathrm{Q}_{\mathrm{nb}} \\
(\mathrm{J} / \mathrm{s})\end{array}$ & $\begin{array}{c}\mathrm{X}_{\mathrm{db}} \\
(\mathrm{N})\end{array}$ \\
\hline 0.2 & 5.70 & 0.393 & 8.45 & 13867.30 & 16.13 & 351.92 & 586.53 & 272.48 & $658,807,320.43$ \\
\hline 0.3 & 5.15 & 0.574 & 8.69 & 14243.09 & 24.20 & 554.40 & 924.00 & 272.17 & $669,461,828.60$ \\
\hline 0.4 & 4.60 & 0.754 & 8.82 & 14444.77 & 32.27 & 758.43 & 1264.05 & 271.86 & $675,133,534.83$ \\
\hline 0.5 & 4.05 & 0.935 & 8.90 & 14574.41 & 40.18 & 963.58 & 1605.97 & 271.55 & $678,762,575.71$ \\
\hline 0.6 & 3.507 & 1.115 & 8.96 & 14668.43 & 48.40 & 1169.85 & 1949.75 & 271.24 & $681,386,384.17$ \\
\hline 0.7 & 2.958 & 1.296 & 9.01 & 14743.59 & 56.47 & 1377.45 & 2295.75 & 270.93 & $683,478,988.98$ \\
\hline 0.8 & 2.41 & 1.476 & 9.05 & 14809.47 & 64.54 & 1586.85 & 2644.75 & 270.61 & $685,309,846.40$ \\
\hline
\end{tabular}

Table 5. Results at $15 \% \mathrm{TS}$

\begin{tabular}{|c|c|c|c|c|c|c|c|c|c|}
\hline$\alpha$ & $\begin{array}{c}\mathrm{Se} \\
(\mathrm{mg} / \mathrm{l})\end{array}$ & $\begin{array}{c}\mathrm{Xe} \\
(\mathrm{mg} / \mathrm{l})\end{array}$ & $\begin{array}{c}\mathrm{t}_{\mathrm{d}} \\
(\text { days })\end{array}$ & $\begin{array}{c}\mathrm{V}_{\mathrm{bd}} \\
\left(\mathrm{m}^{3}\right)\end{array}$ & $\begin{array}{c}\mathrm{E}_{\mathrm{b}} \\
(\%)\end{array}$ & $\begin{array}{c}\mathrm{V}_{\mathrm{m}} \\
\left(\mathrm{m}^{3} \mathrm{CH}_{4} / \mathrm{day}\right)\end{array}$ & $\begin{array}{c}\mathrm{V}_{\mathrm{t}} \\
\left(\mathrm{m}^{3}\right)\end{array}$ & $\begin{array}{c}\mathrm{Q}_{\mathrm{nb}} \\
(\mathrm{J} / \mathrm{s})\end{array}$ & $\begin{array}{c}\mathrm{X}_{\mathrm{db}} \\
(\mathrm{N})\end{array}$ \\
\hline 0.2 & 12.957 & 0.853 & 8.79 & 12041.12 & 16.13 & 760.98 & 1268.29 & 317.54 & $605,289,757.08$ \\
\hline 0.3 & 11.710 & 1.263 & 8.91 & 12180.85 & 24.20 & 1166.72 & 1944.53 & 316.96 & $609,494,503.99$ \\
\hline 0.4 & 10.46 & 1.674 & 8.97 & 12254.28 & 32.27 & 1573.36 & 2622.27 & 316.37 & $611,696,331.81$ \\
\hline 0.5 & 9.22 & 2.084 & 9.00 & 12301.02 & 40.28 & 1980.79 & 3301.31 & 315.79 & $613,095,379.20$ \\
\hline 0.6 & 7.97 & 2.495 & 9.03 & 12334.81 & 48.40 & 2389.08 & 3981.80 & 315.20 & $614,105,071.19$ \\
\hline 0.7 & 6.725 & 2.905 & 9.05 & 12361.83 & 56.47 & 2798.47 & 4664.12 & 314.61 & $614,911,902.66$ \\
\hline 0.8 & 5.479 & 3.315 & 9.07 & 12385.61 & 64.54 & 3209.38 & 5348.96 & 314.02 & $615,621,371.01$ \\
\hline
\end{tabular}


Table 6. Results at $20 \%$ TS

\begin{tabular}{|c|c|c|c|c|c|c|c|c|c|}
\hline$\alpha$ & $\begin{array}{c}\mathrm{Se} \\
(\mathrm{mg} / \mathrm{l})\end{array}$ & $\begin{array}{c}\mathrm{Xe} \\
(\mathrm{mg} / \mathrm{l})\end{array}$ & $\begin{array}{c}\mathrm{t}_{\mathrm{d}} \\
(\text { days })\end{array}$ & $\begin{array}{c}\mathrm{V}_{\mathrm{bd}} \\
\left(\mathrm{m}^{3}\right)\end{array}$ & $\begin{array}{c}\mathrm{E}_{\mathrm{b}} \\
(\%)\end{array}$ & $\begin{array}{c}\mathrm{V}_{\mathrm{m}} \\
\left(\mathrm{m}^{3} \mathrm{CH}_{4} / \mathrm{day}\right)\end{array}$ & $\begin{array}{c}\mathrm{V}_{\mathrm{t}} \\
\left(\mathrm{m}^{3}\right)\end{array}$ & $\begin{array}{c}\mathrm{Q}_{\mathrm{nb}} \\
(\mathrm{J} / \mathrm{s})\end{array}$ & $\begin{array}{c}\mathrm{X}_{\mathrm{db}} \\
(\mathrm{N})\end{array}$ \\
\hline 0.2 & 23.27 & 1.507 & 8.92 & 11494.00 & 16.13 & 1346.85 & 2244.75 & 362.36 & $588,663,903.04$ \\
\hline 0.3 & 21.04 & 2.244 & 8.98 & 11564.55 & 24.20 & 2044.72 & 3407.86 & 461.38 & $590,714,729.90$ \\
\hline 0.4 & 18.80 & 2.981 & 9.01 & 11597.87 & 32.27 & 2743.26 & 4572.10 & 360.39 & $591,820,835.21$ \\
\hline 0.5 & 16.56 & 3.718 & 9.03 & 11620.67 & 40.28 & 3442.46 & 5737.43 & 359.40 & $592,518,470.39$ \\
\hline 0.6 & 14.32 & 4.456 & 9.04 & 11637.00 & 48.40 & 4142.44 & 6904.06 & 358.42 & $593,018,131.80$ \\
\hline 0.7 & 12.08 & 5.193 & 9.07 & 11653.57 & 56.47 & 4843.42 & 8072.37 & 357.42 & $593,524,458.26$ \\
\hline 0.8 & 9.84 & 5.93 & 9.08 & 11655.17 & 64.54 & 5545.81 & 9243.01 & 356.43 & $593,879,083.26$ \\
\hline
\end{tabular}

Table 7. Results at $25 \% \mathrm{TS}$

\begin{tabular}{|c|c|c|c|c|c|c|c|c|c|}
\hline$\alpha$ & $\begin{array}{c}\mathrm{Se} \\
(\mathrm{mg} / \mathrm{l})\end{array}$ & $\begin{array}{c}\mathrm{Xe} \\
(\mathrm{mg} / \mathrm{l})\end{array}$ & $\begin{array}{c}\mathrm{t}_{\mathrm{d}} \\
(\text { days })\end{array}$ & $\begin{array}{c}\mathrm{V}_{\mathrm{bd}} \\
\left(\mathrm{m}^{3}\right)\end{array}$ & $\begin{array}{c}\mathrm{E}_{\mathrm{b}} \\
(\%)\end{array}$ & $\begin{array}{c}\mathrm{V}_{\mathrm{m}} \\
\left(\mathrm{m}^{3} \mathrm{CH}_{4} / \mathrm{day}\right)\end{array}$ & $\begin{array}{c}\mathrm{V}_{\mathrm{t}} \\
\left(\mathrm{m}^{3}\right)\end{array}$ & $\begin{array}{c}\mathrm{Q}_{\mathrm{nb}} \\
(\mathrm{J} / \mathrm{s})\end{array}$ & $\begin{array}{c}\mathrm{X}_{\mathrm{db}} \\
(\mathrm{N})\end{array}$ \\
\hline 0.2 & 36.75 & 2.36 & 8.97 & 11633.92 & 16.13 & 2159.94 & 3599.89 & 406.84 & $592,923,879.07$ \\
\hline 0.3 & 33.22 & 3.52 & 9.02 & 11675.09 & 24.20 & 3264.13 & 5440.22 & 405.27 & $594,181,953.76$ \\
\hline 0.4 & 29.68 & 4.69 & 9.04 & 11696.46 & 32.27 & 4368.91 & 7281.52 & 403.71 & $594,834,104.30$ \\
\hline 0.5 & 26.14 & 5.85 & 9.05 & 11709.96 & 40.34 & 5474.30 & 9123.83 & 402.14 & $595,246,159.01$ \\
\hline 0.6 & 22.61 & 7.02 & 9.06 & 11719.68 & 48.40 & 6580.43 & 10967.38 & 400.57 & $595,542,453.40$ \\
\hline 0.7 & 19.07 & 8.18 & 9.07 & 11727.43 & 56.47 & 7687.52 & 12812.54 & 399.01 & $595,778,603.46$ \\
\hline 0.8 & 15.54 & 9.35 & 9.08 & 11734.23 & 64.54 & 8795.98 & 14659.97 & 397.44 & $595,985,852.57$ \\
\hline
\end{tabular}

Table 8. Results at $30 \%$ TS

\begin{tabular}{|c|c|c|c|c|c|c|c|c|c|}
\hline$\alpha$ & $\begin{array}{c}\mathrm{Se} \\
(\mathrm{mg} / \mathrm{l})\end{array}$ & $\begin{array}{c}\mathrm{Xe} \\
(\mathrm{mg} / \mathrm{l})\end{array}$ & $\begin{array}{c}\mathrm{t}_{\mathrm{d}} \\
(\mathrm{days})\end{array}$ & $\begin{array}{c}\mathrm{V}_{\mathrm{bd}} \\
\left(\mathrm{m}^{3}\right)\end{array}$ & $\begin{array}{c}\mathrm{E}_{\mathrm{b}} \\
(\%)\end{array}$ & $\begin{array}{c}\mathrm{V}_{\mathrm{m}} \\
\left(\mathrm{m}^{3} \mathrm{CH}_{4} / \mathrm{day}\right)\end{array}$ & $\begin{array}{c}\mathrm{V}_{\mathrm{t}} \\
\left(\mathrm{m}^{3}\right)\end{array}$ & $\begin{array}{c}\mathrm{Q}_{\mathrm{nb}} \\
(\mathrm{J} / \mathrm{s})\end{array}$ & $\begin{array}{c}\mathrm{X}_{\mathrm{db}} \\
(\mathrm{N})\end{array}$ \\
\hline 0.2 & 53.48 & 3.42 & 9.01 & 12213.57 & 16.13 & 3260.32 & 5433.87 & 450.84 & $610,476,461.00$ \\
\hline 0.3 & 48.34 & 5.11 & 9.04 & 12240.79 & 24.20 & 4914.98 & 8191.63 & 448.46 & $611,292,394.56$ \\
\hline 0.4 & 43.19 & 6.81 & 9.05 & 12254.89 & 32.27 & 6570.18 & 10950.29 & 446.07 & $611,714,594.21$ \\
\hline 0.5 & 38.05 & 8.50 & 9.06 & 12263.79 & 40.34 & 8225.96 & 13709.94 & 443.69 & $611,981,093.46$ \\
\hline 0.6 & 32.90 & 10.20 & 9.07 & 12270.18 & 48.40 & 9882.48 & 16470.80 & 441.31 & $612,172,601.24$ \\
\hline 0.7 & 27.76 & 11.89 & 9.07 & 12275.28 & 56.47 & 11539.97 & 19233.28 & 438.92 & $612,325,165.78$ \\
\hline 0.8 & 22.62 & 13.59 & 9.08 & 12279.75 & 64.54 & 13198.81 & 21998.02 & 436.54 & $612,459,013.28$ \\
\hline
\end{tabular}

Table 9. Summary Results for Various PTS Concentrations

\begin{tabular}{|c|c|c|c|c|c|c|c|c|c|c|}
\hline $\begin{array}{c}\text { PTS } \\
(\%)\end{array}$ & $\begin{array}{c}\mathrm{TS} \\
(\%)\end{array}$ & $\begin{array}{c}\mathrm{VS} \\
(\%)\end{array}$ & $\begin{array}{c}\mathrm{S}_{\mathrm{e}} \\
(\mathrm{mg} / \mathrm{l})\end{array}$ & $\begin{array}{c}\mathrm{X}_{\mathrm{e}} \\
(\mathrm{mg} / \mathrm{l})\end{array}$ & $\begin{array}{c}\mathrm{t}_{\mathrm{d}} \\
(\mathrm{days})\end{array}$ & $\begin{array}{c}\mathrm{V}_{\mathrm{bd}} \\
\left(\mathrm{m}^{3}\right)\end{array}$ & $\begin{array}{c}\mathrm{V}_{\mathrm{m}} \\
\left(\mathrm{m}^{3} \mathrm{CH}_{4} / \mathrm{d}\right)\end{array}$ & $\begin{array}{c}\mathrm{V}_{\mathrm{t}} \\
\left(\mathrm{m}^{3}\right)\end{array}$ & $\begin{array}{c}\mathrm{Q}_{\mathrm{nb}} \\
(\mathrm{J} / \mathrm{s})\end{array}$ & $\begin{array}{c}\mathrm{X}_{\mathrm{db}} \\
(\mathrm{N})\end{array}$ \\
\hline 10 & 31186.84 & 20770.43 & 2.41 & 1.48 & 9.05 & $14,809.47$ & 1586.85 & 2644.75 & 270.61 & $685,309,846.40$ \\
\hline 15 & 54603.04 & 36365.62 & 5.48 & 3.32 & 9.07 & $12,385.61$ & 3209.38 & 5348.96 & 314.02 & $615,621,371.01$ \\
\hline 20 & 83234.43 & 55434.13 & 9.84 & 5.93 & 9.08 & $11,665.17$ & 5545.81 & 9243.01 & 356.43 & $593,879,083.26$ \\
\hline 25 & 117081.02 & 77975.96 & 15.54 & 9.35 & 9.08 & $11,734.23$ & 8795.98 & 14659.97 & 397.44 & $595,985,852.57$ \\
\hline 30 & 156142.00 & 103991.10 & 53.48 & 13.59 & 9.08 & $12,279.75$ & 13198.81 & 21998.02 & 436.54 & $612,459,013.28$ \\
\hline
\end{tabular}

\section{REFERENCES}

[1] Igoni, A. H., Eze, C. L., Ayotamuno, M. J., and Abowei, M. F. N. (2005). Potentials of Biogas Generation from Municipal Solid Waste in Port Harcourt Metropolis, Proceedings of the $1^{\text {st }}$ annual Conference of Science and technology Forum, Uyo, Nigeria. Vol1, No. 2, pp 67-72.
[2] Byrne, K. (1997): Environmental Science, Thomas Nelson \& Sons Ltd, Uk. 206 p

[3] Bailie, R. C., Everett, J. W., Liptak, B. G., Liu, D. H. F., Rugg, F. M. and Switzenbaum, M. S. (1996). Solid Waste, In Environmental Engineers Handbook. (Eds) Liu, D. H. F., Liptak, B. G., and Bouis, P. A., Lewis Publishers, New York. 1148-1248.

[4] Sincero, A. P. and Sincero, G. A. (1999). Environmental 
Engineering - A Design Approach. Prentice-Hall of India Private Limited, New Delhi. 795p.

[5] Ogunbiyi, A. (2001). Local Technology in Solid Waste Management in Nigeria. Proceedings of the National Engineering Conference and Annual General Meeting of the Nigerian Society of Engineers. Pp. 73-79.

[6] Kiely, G. (1998). Environmental Engineering, International Edition, Irwin McGraw-Hill, Boston. 979p

[7] Igoni, A. H. (2006). Design of Anaerobic Bioreactors for Simulation of Biogas Production from Municipal Solid Waste. $\mathrm{PhD}$ Thesis, Rivers State University of Science and Technology, Nigeria. 261pp

[8] Igoni, A. H. (2016). Analyses of Anaerobic Batch Digestion of Municipal Solid Waste in the Production of Biogas Using Mathematical Models; Energy and Environment Research; Vol. 6, No. 1; pp44-56. URL: http://dx.doi.org/10.5539/eer.v $6 \mathrm{n} 1 \mathrm{p} 44$

[9] Itodo, I. N. and Phillips, T. K. (2001). Determination of Suitable Material for Anaerobic Biogas Digesters; Proceedings of the $2^{\text {nd }}$ International Conference and 23rd Annual General Meeting of the Nigerian Institution of Agricultural Engineers. Vol. 23 Pp. 437-441.

[10] General Environmental Multilingual Thesaurus (GEMET), 2000. Biomass Resources

http://glossary.eea.eu.int./EEAGlossary/B/Biogas

[11] Hobson, P. N., Bousfield, S., and R. Summers (1981). Methane Production from Agricultural and Domestic Wastes, Applied Science Publishers Ltd., London. 269p

[12] Mattocks, R. (1984). Understanding Biogas Generation, Technical Paper No. 4. Volunteer in Technical Assistance, Virginia, USA. 13p

[13] Xuereb, P. (1997): Biogas-A Fuel Produced from Waste; http://www.synapse.net.mt/mirin/newsletter/3836.asp. 2p.

[14] Oregon State Department of Energy (2002). Biomass Energy Technology [Online]; Available; www.oregondoe.org. 19p

[15] Seedtree Biogas Program (2003).http:/www.seedtree.org/bio gas.html. $6 \mathrm{p}$

[16] Harris, P. (2003): Beginners Guide to Biogas: http://www.ees.adelaide.edu.au/pharis/biogas/beginners/html. $11 \mathrm{p}$

[17] Madu, C. and Sodeinde, O. A. (2001). Relevance of Biomass in the Sustainable Energy Development in Nigeria, Proceedings of the National Engineering Conference and Annual General Meeting of the Nigerian Society of Engineers. Pp220-227.

[18] Steadman, P. (1975). Energy, Environment and Building, A Report to The Academy of Natural Sciences of Philadelphia, Cambridge University Press, Cambridge, London. 287p.

[19] Igoni, A. H., Abowei, M. F. N., Ayotamuno, M. J. and Eze, C. L. (2006). "Biokinetics of Anaerobic Digestion of Municipal Solid Waste". New views Engineering Analysis and Modelling, Vol. 1, No. 1, 98-112.

[20] Igoni, A. H., Ayotamuno M. J., Ogaji, S. T., \& Probert, S. D. (2007). Municipal Solid Waste in Port Harcourt, Nigeria. Applied Energy, 84(6), 664-670
[21] Chawla, O. P. (1986). Advances in Biogas Technology, India Corporation of Agricultural Research. 28p

[22] Reynolds, T. D. And Richards, P. A. (1996): Units Operations and Processes in Environmental Engineering, Second Edition, PWS Publishing Company, Boston. 798p

[23] Stewart, W. C. (2014). Three stage, multiple phase anaerobic digestion system and method US Patent 8765449 B2, filed July 31, 2009 and published July 1, 2014.

[24] Eckenfelder, W. W. Jr (2000). Industrial Water Pollution Control. McGraw-Hill Higher Education, Boston Burr Ridge, pp394-411.

[25] Levenspiel, O. (1999). Chemical Reaction Engineering, $\left(3^{\text {rd }}\right.$ Edition). John Wiley and Sons, Inc; New York. 668p.

[26] American Public Health Association (APHA). (1995). Standard Methods for the Examination of Water and Wastewater, $19^{\text {th }}$ Edition; Greenberg A. E. (Ed). Byrd Springfield, Washington D. C. 1100pp

[27] Walkley, A. and Black, I. A. (1934). An examination of the Degtjareff Method for Determining Soil Organic Matter and a Proposed Modification of the Chromic Acid Titration Method. Soil Science. 37: 29-37

[28] Andrews, J. F. (1978): The Development of a Dynamic Model and Control Strategies for the Anaerobic Digestion Process. In James, A (Ed.) Mathematical Models in Water Pollution Control; John Wiley \& Sons, Chichester. 420p

[29] Tchobanoglous, G; Burton, F. L. and Stensel, H. D (2003). Wastewater Engineering: Treatment and Reuse. Tata McGraw-Hill Publishing Company Limited, New Delhi. $1819 \mathrm{p}$

[30] Monod, J. (1949). The Growth of Bacterial Cultures, Annual Review of Microbiology, Vol 111.

[31] Tchobanoglous, G; and Burton, F. L. (1991). Wastewater Engineering: Treatment, Disposal and Reuse. Third Edition. McGraw-Hill Inc., New York. 1334p

[32] Raymus, G. J. (1997). Handling of Bulk Solids and Packaging of Solids and Liquids. In Perry, H. R., Green, W. D., and Maloney, J. O. (Eds.): Perry's Chemical Engineering Handbook. $7^{\text {th }}$ Edition. McGraw-Hill Publishers, New York. $78 \mathrm{p}$.

[33] Evseev, M. K. (1972). Mechanization and Electrification of Livestock Production. Kolos, Moscow. 415p

[34] Peter, M. S. and Timmerhaus, K. D. (1981). Plant Design and Economics. McGraw-Hill Book Company, Tokyo. P537.

[35] Whitesides, R. W. (2001): "Process Equipment Cost Estimating by Ratio and Proportion - a PDH online Course. www.PDHcenter.com. 8p

[36] Bushwell, A. M. and Mueller, H. F. (1952). Mechanics of Methane Fermentation. Journal of Industrial Engineering Chemistry, 44(3), 550.

[37] Graef, S. P. and Andrews, J. F. (1973). Mathematical Modelling and Control of Anaerobic Digestion, in C. F. Bennett (Ed), Water, Chemical Engineering Progress Symposium Series, No. 136, Vol. 79, p 101. 
[38] Perry, H. R. and Green, W. D. (1997). Perry's Chemical Engineering Handbook. $7^{\text {th }}$ Edition. McGraw-Hill Publishers, New York. P21 -8.

[39] Viessman, W. (Jr) and Hammer, M. J. (1993): Water Supply and Pollution Control. Harper Collins College Publishers New York, pp513-679.
[40] Tchobanoglous, G; Theisen, H. and Vigil, S. (1993): Integrated Solid Waste Management: Engineering Principles and Management Issues. McGraw-Hill Inc. New York. 978 